\title{
PENGARUH METODE PEMBELAJARAN DISCOVERY LEARNING TERHADAP HASIL BELAJAR SISWA PADA MATERI POKOKFLUIDA DINAMIS
}

\author{
Widya Tari Rhamadani dan Rita Juliani \\ Jurusan Fisika FMIPA Universitas Negeri Medan \\ Jalan Willem Iskandar Pasar V Medan, Sumatera Utara \\ widyatari.rhamadani@yahoo.co.id
}

\begin{abstract}
ABSTRAK
Penelitian yang telah dilakukan bertujuan untuk mengetahui pengaruh metode discovery learning terhadap hasil belajar fisika pada materi fluida dinamis di SMA Swasta Budi Satrya Medan. Jenis penelitian ini adalah quasi experiment. Populasi dalam penelitian adalah seluruh siswa kelas XI yang terdiri dari 4 kelas. Pengambilan sampel dilakukan dengan cara cluster random sampling dengan mengambil 2 kelas secara acak, yaitu kelas XI-1 sebagai kelas eksperimen dan kelas XI-2 sebagai kelas kontrol. Hasil penelitian menunjukkan nilai rata-rata postes kelas eksperimen 72,50 dan kelas kontrol 64.00. Hasil uji t satu pihak dengan taraf signifikasi 0,05 diperoleh $\mathrm{t}_{\text {hitung }}=2,88$ dan $\mathrm{t}_{\text {tabel }}$ $=2,002$ sehingga $t_{\text {hitung }}>t_{\text {tabel }}$ maka disimpulkan bahwa ada perbedaan akibat pengaruh metode discovery learning terhadap hasil belajar siswa pada materi pokok fluida dinamis kelas XI.
\end{abstract}

Kata kunci : metode discovery learning, hasil belajar

\begin{abstract}
This research aimed to know the effect of discovery learning method upon the learning outcomes of physic in dynamic fluid at Senior High School Swasta Budi Satrya Medan. This research based on quasy of experiment. Population used in this research is all students grade XI consist of 4 classes. The method of this research is taken by cluster random sampling where XI-1 as experiment class and XI-2 as control class. The result showed that the average of posttest on experiment class is 72,50 and control class is 64.00. The result of $t$-test with significance is 0,05 obtained tarithmatic $=2,88$ adn $t_{\text {table }}=$ 2,002 so $t_{\text {arithmatic }}>t_{\text {table }}$ and can be concluded that there is different of effect discovery learning method upon the learning outcomes of physic in dynamic fluid on XI class.
\end{abstract}

Keyword: method of discovery learning, learning outcomes

\section{INTRODUCTION}

Perkembangan pendidikan di Indonesia dari tahun ke tahun mengalami perubahan seiring dengan tantangan dalam menyiapkan sumber daya manusia yang berkualitas dan mampu bersaing di era global. Salah satu permasalahan yang dihadapi oleh bangsa adalah masih rendahnya kualitas pendidikan pada setiap jenjang. Meningkatkan kualitas pendidikan di Indonesia, proses kegiatan belajar mengajar di sekolah merupakan kegiatan yang sangat penting. Sementara masalah yang dihadapi dunia pendidikan adalah masalah lemahnya proses pembelajaran peserta didik dalam memahami suatu konsep.

Berdasarkan hasil studi pendahuluan menggunakan observasi dapat disimpulkan bahwa proses pembelajaran tidak berpusat 
pada siswa, yang mengakibatkan siswa tidak berperan aktif dalam memperoleh pengetahuan. Siswa kurang motivasi dalam belajar sehingga siswa tidak bersemangat dan dalam pembelajaran siswa bersifat menjadi pendengar saja dan guru yang bersifat dominan (teacher centered).

Berdasarkan masalah di atas, salah satu cara yang dapat digunakan untuk mengatasinya adalah dengan menggunakan model pembelajaran yang berpusat pada siswa (student center learning). Dengan aktifnya siswa dalam pembelajaran maka diharapkan pembelajaran akan lebih bermakna karena siswa secara langsung diajak untuk mengkonstruksi pengetahuannya. Disini penulis menawarkan sebuah metode discovery learning. Model discovery learning adalah suatu cara untuk menghimpun informasi, membandingkan, mengkatagorikan, menganalisis, mengintegrasikan, mengorganisasikan bahan serta membuat kesimpulan-kesimpulan. Model pembelajaran discovery learning terdiri dari rangkaian tahap-tahap kegiatan (fase) yang diorganisasikan sedemikian rupa membentuk suatu sesinambungan sehingga pembelajar dapat menguasai kompetensikompetensi yang harus dicapai dalam pembelajaran dengan jalan berperan aktif.

\section{METODE PENELITIAN}

Penelitian dilakukan di SMA Swasta Budi Satrya Medan J1. Letda Sudjono No 166 Medan pada bulan April sampai Mei 2015.

Populasi dalam penelitian adalah seluruh siswa kelas XI SMA Swasta Budi Satrya Medan T.P 2014/2015 yang terdiri atas 4 kelas. Pengambilan sampel dilakukan dengan cluster random sampling, diambil 2 kelas yaitu kelas XI-1 sebagai kelas eksperimen diajarkan mode discovery learning dan kelas XI-2 sebagai kelas kontrol diajarkan dengan pembelajaran konvensional.

Jenis penelitian quasi experiment. Quasi experimen didefinisikan sebagai eskperimen yang memiliki perlakuan, pengukuran dampak unit eksperimen namun tidak menggunakan penugasan acak untuk menciptakan perbandingan dalam rangka menyimpulkan perubahan yang disebabkan perlakuan (Cook \& Campbell dalam Wicaksono, dkk., 2011).

Desain penelitian ini adalah pre-test and post-test group. Desain penelitian dapat dilihat pada Tabel 1 (Arikunto, 2006).

Tabel 1. Pre-test and Post-test Group

\begin{tabular}{cccc} 
Kelas & Pretes & $\begin{array}{c}\text { Perla- } \\
\text { kuan }\end{array}$ & Postes \\
\hline Eksperimen & $\mathrm{Y}_{1}$ & $\mathrm{X}_{1}$ & $\mathrm{Y}_{2}$ \\
\hline Kontrol & $\mathrm{Y}_{1}$ & $\mathrm{X}_{2}$ & $\mathrm{Y}_{2}$
\end{tabular}

Keterangan :

$$
\begin{aligned}
\mathrm{Y}_{1}= & \text { Tes awal }(\text { Pre-test }) \\
\mathrm{Y}_{2}= & \text { Tes akhir (Post-test) } \\
\mathrm{X}_{1}= & \text { Pembelajaran dengan model } \\
& \text { discovery learning } \\
\mathrm{X}_{2}= & \text { Pembelajaran konvensional. }
\end{aligned}
$$

Pengumpulan data dilakukan dengan metode observasi dan metode tes. Instrumen yang dipersiapkan antara lain: perangkat pembelajaran, lembar pengamatan, dan tes pilihan berganda sebanyak 20 soal dengan 5 pilihan.

\section{HASIL DAN PEMBAHASAN}

Hasil tes yang telah dilakukan di SMA Swasta Budi Satrya Medan diperoleh data pretes untuk kelas eksperimen dengan jumlah siswa 30 orang memperoleh nilai rata-rata pretes sebesar 25,33 dan untuk kelas kontrol dengan jumlah siswa 30 orang memperoleh nilai rata-rata pretes sebesar

\begin{tabular}{|c|c|c|c|c|c|}
\hline \multicolumn{3}{|c|}{$\begin{array}{c}\text { Data nilai pretes kelas } \\
\text { eksperimen }\end{array}$} & \multicolumn{3}{|c|}{$\begin{array}{c}\text { Data nilai pretes kelas } \\
\text { kontrol }\end{array}$} \\
\hline$\overline{\text { Nilai }}$ & $\begin{array}{c}\text { Freku } \\
\text { ensi }\end{array}$ & $\begin{array}{c}\text { Rata- } \\
\text { rata }\end{array}$ & Nilai & $\begin{array}{c}\text { Freku } \\
\text { ensi }\end{array}$ & $\begin{array}{c}\text { Rata- } \\
\text { rata }\end{array}$ \\
\hline $44-17$ & 5 & 25,33 & 14-17 & 7 & 24,00 \\
\hline $8-21$ & 6 & & $18-21$ & 6 & \\
\hline $2-25$ & 7 & & $22-25$ & 7 & \\
\hline $2 \overline{6-29}$ & $\overline{0}$ & & $26-29$ & 0 & \\
\hline $3 \overline{0-33}$ & 6 & & $30-33$ & 6 & \\
\hline
\end{tabular}
24.00. Data yang diperoleh ditunjukkan pada Tabel 2.

Tabel 2. Data Nilai Pretes Kelas Eksperimen dan Kelas Kontrol 


\begin{tabular}{cc}
\hline $34-37$ & 6 \\
\hline Jumlah & 30
\end{tabular}

\begin{tabular}{cc}
\hline $34-37$ & 4 \\
\hline Jumlah & 30
\end{tabular}

Data postes untuk kelas eksperimen dengan jumlah siswa 30 orang memperoleh nilai rata-rata sebesar 72,50 . Untuk kelas kontrol dengan jumlah siswa 30 orang memperoleh nilai rata-rata pretes sebesar 64,00. Data yang diperoleh ditunjukkan pada Tabel 3.

Tabel 3. Data Nilai Postes Kelas

Eksperimen dan Kelas Kontrol

Data Nilai Postes Kelas Data Nilai Postes Kelas

\begin{tabular}{|c|c|c|c|c|c|}
\hline \multicolumn{3}{|c|}{ Eksperimen } & \multicolumn{3}{|c|}{ Kontrol } \\
\hline Nilai & $\begin{array}{c}\text { Freku } \\
\text { ensi }\end{array}$ & $\begin{array}{l}\text { Rata- } \\
\text { rata }\end{array}$ & Nilai & $\begin{array}{c}\begin{array}{c}\text { Freku } \\
\text { ensi }\end{array}\end{array}$ & $\begin{array}{l}\text { Rata- } \\
\text { rata }\end{array}$ \\
\hline $39-47$ & 0 & & $39-47$ & 2 & \\
\hline $48-56$ & 4 & & $48-56$ & 7 & \\
\hline $57-65$ & 7 & & $57-65$ & 9 & \\
\hline $66-74$ & 3 & 72,50 & $66-74$ & 5 & 64.00 \\
\hline $75-83$ & 9 & & $75-83$ & 6 & \\
\hline $84-92$ & 7 & & $84-92$ & 1 & \\
\hline Jumlah & 30 & & Jumlah & 30 & \\
\hline
\end{tabular}

\section{Pembahasan}

Hasil penelitian menunjukkan bahwa ada pengaruh yang signifikan menggunakan metode discovery learning terhadap hasil belajar fisika pada materi pokok fluida dinamis di kelas XI semester Genap SMA Swasta Budi Satrya Medan T.P. 2014/2015.

Hasil penelitian terhadap kelas eksperimen menggunakan model discovery learning terhadap hasil belajar siswa pada materi fluida dinamis di kelas XI semester II SMA Swasta Budi Satrya Medan T.P. 2014/2015 menunjukkan adanya peningkatan hasil belajar yang signifikan. Hal ini ditunjukkan dengan meningkatnya hasil belajar siswa dari nilai rata-rata pretes kelas eksperimen sebesar 25,33 dan tidak ada seorang pun siswa yang lulus KKM sebesar 70 menjadi 72,50 pada nilai ratarata postes dengan jumlah siswa yang lulus KKM sebanyak 20 orang dari 30 siswa.

Hasil penelitian terhadap kelas kontrol dengan menggunakan pembelajaran konvensional terhadap hasil belajar siswa pada materi pokok fluida dinamis di kelas XI semester genap SMA Swasta Budi
Satrya Medan T.P. 2014/2015 juga menunjukkan adanya peningkatan hasil belajar. Ditunjukkan dengan meningkatnya hasil belajar siswa dari nilai rata-rata pretes kelas kontrol sebesar 24,00 dan tidak ada seorang pun siswa yang mencapai KKM sebesar 70 menjadi sebesar 64,00 pada nilai rata-rata postes dengan jumlah siswa yang mencapai KKM sebanyak 11 orang dari 30 orang siswa.

Penelitian mengenai metode pembelajaran discovery learning sudah pernah diteliti oleh peneliti sebelumnya. Peneliti sebelumnya Afendi (2012) mengatakan "model discovery learning memiliki rata-rata lebih baik daripada pembelajaran konvensional. Artinya pembelajaran dengan model discovery learning lebih efektif daripada pembelajaran konvensional terhadap hasil belajar matematika". Balim (2009) menyebutkan "Model pembelajaran penemuan diterapkan memiliki skor total rata-rata lebih tinggi daripada kelompok kontrol yang diterapkan dengan pengajaran tradisional.

Walaupun penggunaan model discovery learning dapat meningkatkan hasil belajar dan aktivitas siswa, tetapi selama pembelajaran masih ada kendala yang dihadapi peneliti yang menyebabkan pencapaian hasil belajar belum maksimal yaitu, pada sintaks identifikasi masalah dan sintaks pengumpulan data. Adapun kegiatan yang terdapat pada sintaks identifikasi masalah adalah membuat hipotesis dari fenomena yang diamati, kebanyakan siswa kurang paham membuat hipotesis. Upaya yang dilakukan adalah agar peneliti selanjutnya mampu menyampaikan fenomena yang lebih nyata kepada siswa. Selain itu kesulitan yang dihadapi peneliti adalah terdapat pada sintaks pengumpulan data. Adapun kegiatan yang dilakukan pada sintaks pengumpulan data adalah mengumpulkan data dari percobaan dan LKS, siswa tidak terbiasa dengan alat-alat laboratorium yang digunakan sehingga peneliti harus mengajarkan penggunaan alat-alat laboratorium tersebut. Pada tahap 
pembentukan konsep yang membutuhkan banyak waktu peneliti tidak dapat melakukannya secara maksimal.

\section{KESIMPULAN DAN SARAN \\ Kesimpulan}

Hasil penelitian yang telah dilakukan diperoleh kesimpulan nilai rata-rata postes pada kelas eksperimen yang diajarkan dengan metode discovery learning sebesar 72,50 . Sedangkan nilai rata-rata postes pada kelas kontrol yang diajarkan dengan metode pembelajaran konvensional sebesar 64,00. Hasil uji hipotesis memberikan nilai $t_{\text {hitung }}=$ 2,88 dan $t_{\text {tabel }}=2,002$, maka $t_{\text {hitung }}>t_{\text {tabel, }}$, menunjukkan bahwa metode discovery learning memberikan pengaruh yang signifikan daripada pembelajaran konvensional dalam meningkatkan hasil belajar siswa pada materi pokok fluida dinamis di kelas XI semester genap SMA Swasta Budi Satrya Medan T.P 2014/2015.

\section{Saran}

Penelitian yang telah di laksanakan mempunyai beberapa saran bagi pihak yang ingin menerapkan model discovery learning selanjutnya, yaitu :
1. Menyampaikan fenomena yang lebih nyata kepada siswa.

2. Mengajarkan penggunaan alat-alat laboratorium yang akan digunakan.

\section{DAFTAR PUSTAKA}

Afendi, A., (2012), Efektivitas Penggunaan Metode Discovery Learning Terhadap Hasil Belajar Kelas X SMK Diponegoro Yogyakarta., Skripsi, Fakultas Sains Dan Teknologi, UIN Sunan Kalijaga, Yogyakarta.

Arikunto, S., (2006), Prosedur Penelitian, PT. Rineka Cipta, Jakarta.

Balim, A. L., (2009), The Effects of Discovery Learning on Students' Success and Inquiry Learning Skills. Egitim Arastirmalari-Eurasian Journal of Educational Research (35): 1-20.

Wicaksono, S.R., Ferdianto, J., dan Suprapto, E., (2011), Desain Penelitian Menggunakan Quasi Experiment, http://www.slideshare.net/soetam/ku asi-eksperimen (accessed 7 Maret 2015). 